\title{
Reconstruction of large chest wall defects using three-dimensional custom-made implant technology
}

\author{
Kişiye özel üç boyutlu implant teknolojisi kullanılarak geniş göğüs duvarı defektlerinin rekonstrüksiyonu
}

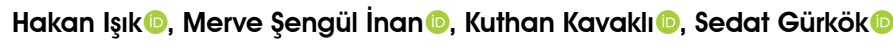

Department of Thoracic Surgey, University of Health Sciences, Gülhane Training and Research Hospital, Ankara, Turkey

\begin{abstract}
It is a challenging issue for thoracic surgeons to repair and reconstruct large defects after chest wall resection without disturbing pulmonary functions. Currently, it is possible to produce nearly the same prosthesis anatomically as the original with the three-dimensional printer technology. Titanium-alloy prostheses produced with the three-dimensional prototyping technology by selective laser sintering technique meet the sensitive needs of reconstruction without impairing the functionality of the tissue. This custom-made titanium prostheses can be used for this purpose safely and effectively as a good alternative.
\end{abstract}

Keywords: Chest wall reconstruction, custom-made prosthesis, threedimensional printer, titanium prosthesis.

Wide chest wall resection may be required for a variety of pathologies such as malignancy, infection, trauma and locally aggressive benign lesions. Reconstruction of a defect, particularly following a wide anterior chest wall resection, is challenging for surgeons, as it often requires a multidisciplinary approach. A variety of different techniques and materials have been proposed to deal with this challenge so far. ${ }^{[1]}$ These methods and materials have different advantages and disadvantages, but the main problem is that it is limited to customize them according to the patient. The most suitable construction material can be designed digitally with the help of imaging methods in a short time.

\section{$\ddot{O} Z$}

Göğüs duvarı rezeksiyonu sonrası oluşan geniş defektlerin solunum fonksiyonlarını bozmadan onarılması ve rekonstrüksiyonu göğüs cerrahları için zor bir durumdur. Günümüzde üç boyutlu yazıcı teknolojisi ile anatomik olarak neredeyse orijinali ile aynı protezlerin üretilmesi mümkündür. Selektif lazer kalıplama tekniği kullanılarak, üç boyutlu prototipleme teknolojisi ile üretilen titanyum alaşım protezler, dokunun fonksiyonelliğini bozmadan rekonstrüksiyonun hassas ihtiyaçlarını karşılar. Bu özel yapım titanyum protezler, bu amaç için iyi bir alternatif olarak güvenli ve etkili bir şekilde kullanılabilir.

Anahtar sözcükler: Göğüs duvarı rekonstrüksiyonu, kişiye özel protez, üç boyutlu yazıcı, titanyum protez.

In this article, we present two case reports whose defects were successfully reconstructed with three-dimensional (3D), custom-made titanium implants (CTIs) using by this method.

\section{CASE REPORT}

Case 1- A 64-year-old female patient who received six cycles of chemotherapy following left mastectomy for breast cancer was referred to our clinic with a sternal mass. The sternal lesion was compatible with metastasis, and no other distant metastasis was detected. The conventional reconstruction methods would not be sufficient for a large tissue defect after resection; therefore, we

Received: January 22, 2020 Accepted: March 11, 2020 Published online: January 13, 2021

Correspondence: Hakan Işık, MD. Gülhane Eğitim ve Araştırma Hastanesi Göğüs Cerrahisi Kliniği, 06010 Keçiören, Ankara, Türkiye. Tel: +90 533 - 7347174 e-mail: hakan_hj@hotmail.com

Işık H, İnan MŞ, Kavaklı K, Gürkök S. Reconstruction of large chest wall defects using three-dimensional custom-made implant technology Turk Gogus Kalp Dama 2021;29(1):122-125 


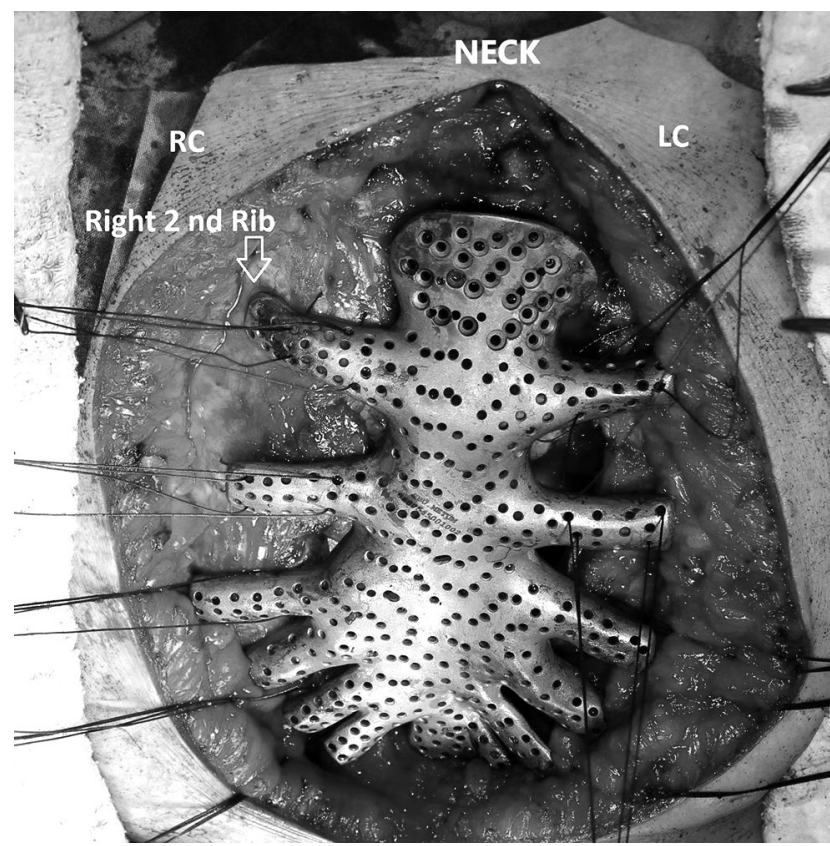

Figure 1. A perioperative view. Sutures are fixed through holes on prosthesis.

RC: Right clavicula; LC: Left clavicula.

decided to use a CTI. A written informed consent was obtained from the patient. The en-bloc resection of lower half of the manubrium, corpus sternum, and related cartilaginous ribs and mass was performed. The titanium implant was placed to cover the defect, and the upper part was fixed to upper half of the manubrium by four titanium screws. The costal extensions of the prosthesis were fixed by suturing the corresponding bone ribs (Figure 1). The patient was discharged on postoperative Day 10 and followed without any problem at 20 months.
Case 2- A 50-year-old male patient was admitted to our clinic with a mass filling the right hemithorax and anterior mediastinal area and protruded from the anterior chest wall (Figure 2). The pathological diagnosis of a Tru-cut biopsy was chondroid neoplasm. The mass was resected with lower half of the manubrium. The chest wall was stabilized by two titanium bridges and a polytetrafluoroethylene (PTFE) mesh. In the postoperative period, a flail chest and type 2 respiratory failure were encountered and, therefore, we decided to use CTI for reconstruction (Figure 3). A written informed consent was obtained from the patient. The implant was fixed to the upper half of manubrium using five titanium screws, and the costal extensions were sutured to the corresponding ribs (Figure 4). In the postoperative period, the paradoxical respiratory movement was terminated, and he was extubated on postoperative Day 5. The patient was discharged three weeks after surgery and followed without any problems at 10 months of discharge (Figure 5).

\section{Design and manufacture of the prosthesis}

Computed tomography (CT) images as Dicom files were converted to stereolithography files, and a 3D digital model was designed. The acrylonitrile butadiene styrene (ABS) plastic prototype was produced in the $3 \mathrm{D}$ printer according to this design. After approval of the ABS model by the surgeon, the digital 3D model was transferred to selective metal laser sintering (SLS) machine. The titanium implant was generated from powder Ti6Al4V ELI Grade 23 under $99.9 \%$ argon atmosphere. Following the production of structure, the implant was exposed to heat in a special normalization oven. Once burnishing and polishing processes were completed,
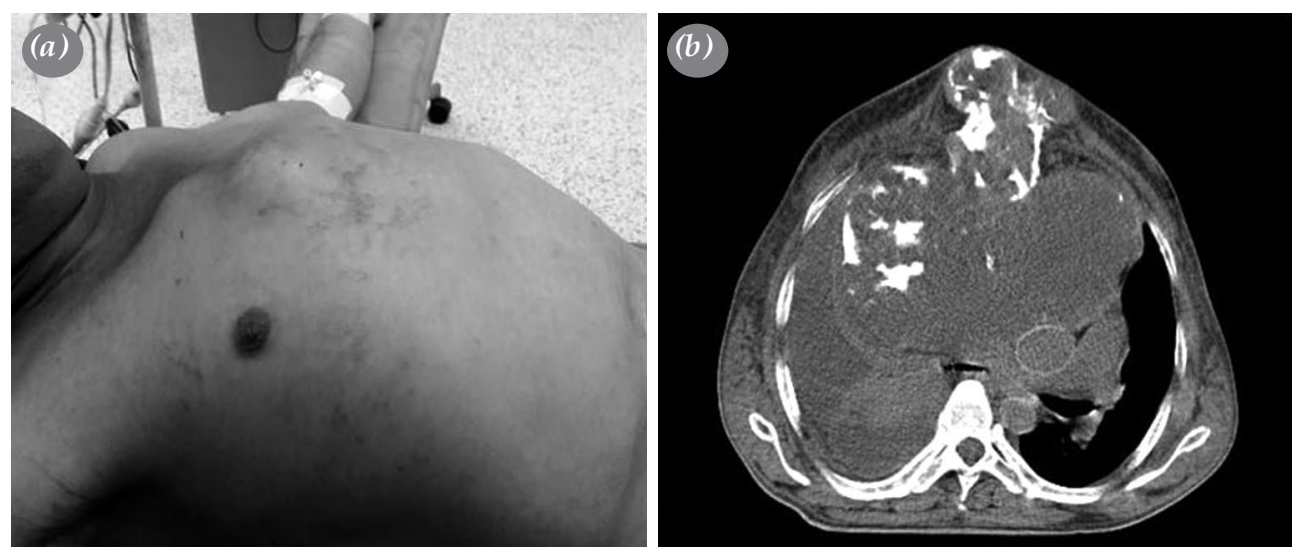

Figure 2. (a) A preoperative view of expansile mass. (b) Computed tomography images showing mass filling whole right hemithorax and compressing mediastinal structures. 


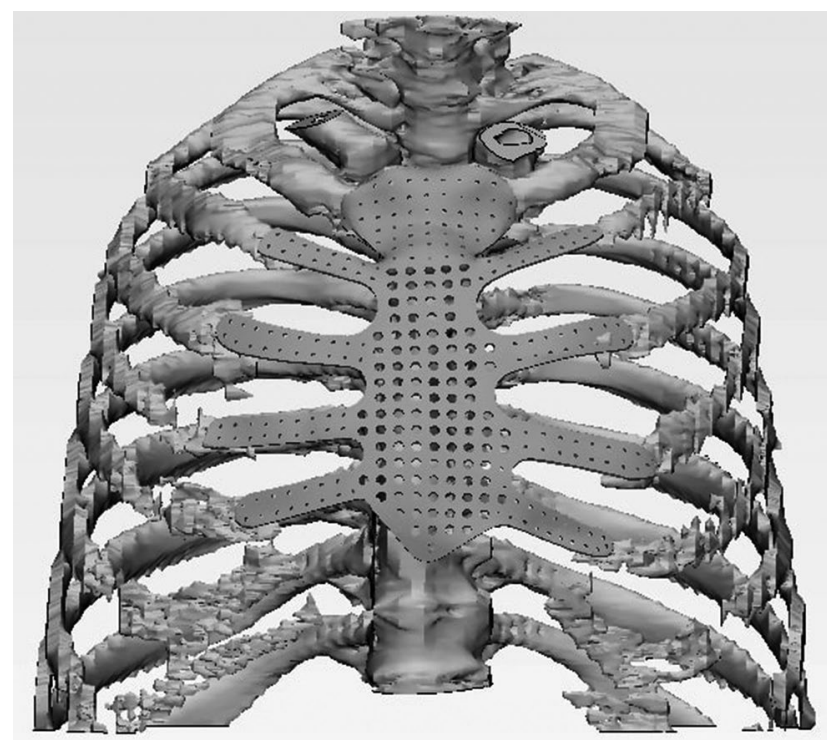

Figure 3. A three-dimensional digital model was created using multi-slice computed tomography images. Simulation of defect after resection was provided and an anatomical prosthesis was planned accordingly.

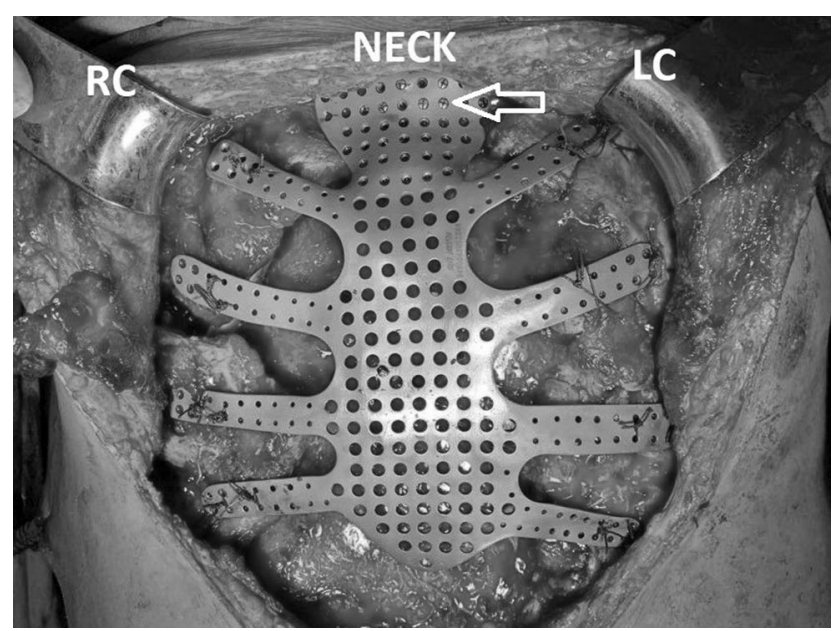

Figure 4. The implant was fixed to upper half of manubrium using five titanium screws (arrow).

RC: Right clavicula; LC: Left clavicula.

the implant structure was sandblasted with 250 , 110 , and 50-micron particle size aluminum oxide (AlO) particles. After sandblasting, the production procedure was completed, and the implant was sterilized by heat in an autoclave.

\section{DISCUSSION}

A flail chest is one of the challenging problems after wide chest wall resections. It can disrupt the

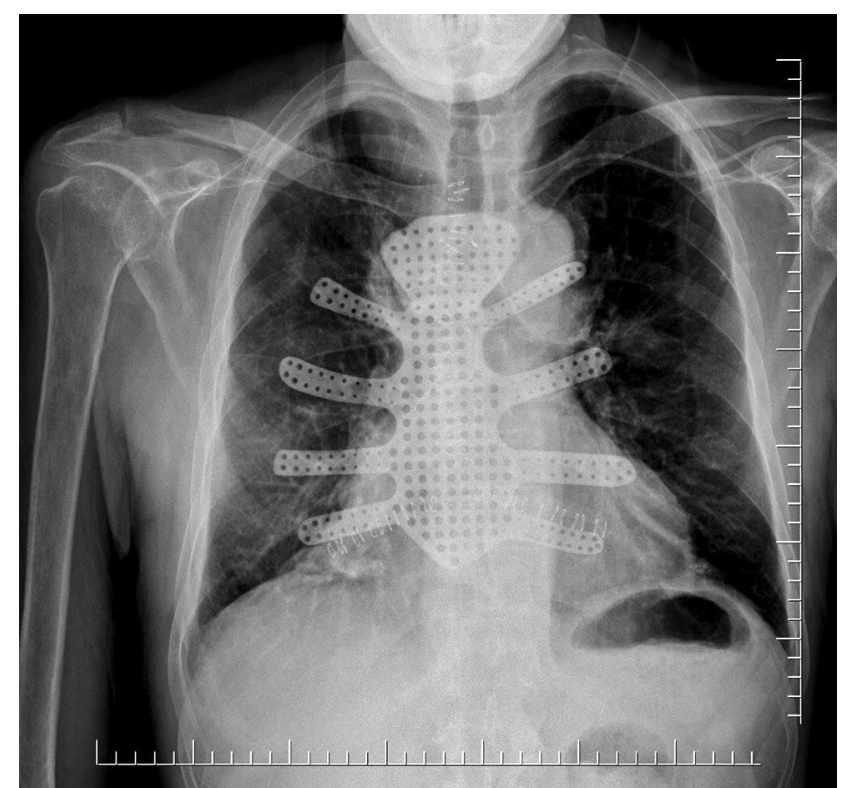

Figure 5. Postoperative chest X-ray of Case 2.

respiratory mechanics of the chest and cause mortal and morbid respiratory complications. Effective stability of the chest wall is, therefore, crucial to prevent the development of a flail chest. ${ }^{[1]}$ In most cases, the use of polypropylene, PTFE, and methyl methacrylate (MMA) meshes alone or in combination yields favorable results. ${ }^{[2]}$

One of the most commonly used techniques is the sandwich method that involves placing MMA between two layers of the Marlex mesh. ${ }^{[3]}$ Although this technique prolongs surgical duration and requires experience, it provides the rigidity needed to maintain respiratory function. ${ }^{[4]}$ However, it is difficult to provide this structure with a concave shape that is specific to the chest wall. Disturbing complications such as pain and fracture have been reported previously. ${ }^{[4]}$ In addition, fluid accumulation and infection can occur behind the implant due to the lack of permeable pores. Chapelier et al. ${ }^{[5]}$ reported that four of 12 patients using a MMA-reinforced mesh developed major septic complications that later required removal of the implant.

The PTFE mesh which adapts well to the shape of the chest wall is a widely used material due to its flexibility. However, it has also several disadvantages, such as poor fibrovascular involvement in the surrounding tissue and low resistance to infection. ${ }^{[6]}$ Titanium is an ideal material for prosthesis due to its low specific weight, corrosion resistance, tensile strength, high biocompatibility, and compatibility with magnetic resonance imaging. ${ }^{[7]}$ 
Three-dimensional prototyping technology by SLS technique has given promising results to surgeons who desire to increase the adaptation of the reconstruction material to respiratory mechanics and to produce the material closest to the original. The 3D model of the bones can be extracted from CT images to allow the surgeon to develop an understanding of the defect that would occur after resection and to design a patient-specific prosthesis. In this way, it is possible to eliminate the defect with a prosthesis produced like a one-to-one copy of the original. In 2013, Turna et al.$^{[8]}$ reported a case of reconstruction of a wide anterior chest wall resection involving the sternum and ribs using a CTI. In addition to the design of the prosthesis in this pioneering publication, designs which provide articulation and flexibility were reported as case reports. ${ }^{[9]}$

In both operations, there was no need to use a mesh to separate the mediastinum from the titanium implant due to the compact structure of the implant. The holes were designed to be compatible with titanium screws to help fit on the implant. The perforated design reduces the cost of the material, production duration, and weight. The perforated structure adheres better to tissues and enables drainage of the seroma that may form behind it. However, while planning this perforated structure, the resistance of the implant should not be impaired.

In conclusion, the availability of this technology which requires experience and pieces of equipment is currently limited. Besides, the cost is higher than that of conventional methods, and it requires more time to manufacture. Based on our experience, the defect formed after a wide resection of the anterior chest wall can be closed effectively and anatomically without disrupting respiratory functions using a titanium alloy prosthesis which is specially manufactured with three-dimensional prototyping technology by the selective laser sintering technique. We believe that patient-specific titanium prosthesis is a good alternative to non-allograft materials.
However, further studies are needed to gain a better insight into this subject.

\section{Acknowledgements}

The titanium materials were designed and produced by Simel Ayyıldız, Safi Serdar Çınar, Burcu Vardar, and İrem Balcı from Gulhane Medical Design and Manufacturing Center. The authors thank them for their significant contribution to this study.

\section{Declaration of conflicting interests}

The authors declared no conflicts of interest with respect to the authorship and/or publication of this article.

\section{Funding}

The authors received no financial support for the research and/or authorship of this article.

\section{REFERENCES}

1. Lardinois D, Müller M, Furrer M, Banic A, Gugger M, Krueger T, et al. Functional assessment of chest wall integrity after methylmethacrylate reconstruction. Ann Thorac Surg 2000;69:919-23.

2. Dingman RO, Argenta LC. Reconstruction of the chest wall. Ann Thorac Surg 1981;32:202-8.

3. McCormack PM. Use of prosthetic materials in chest-wall reconstruction. Assets and liabilities. Surg Clin North Am 1989;69:965-76.

4. Calvin CS Ng. Recent and future developments in chest wall reconstruction. Semin Thorac Cardiovasc Surg 2015;27:234-9.

5. Chapelier AR, Missana MC, Couturaud B, Fadel E, Fabre D, Mussot S, et al. Sternal resection and reconstruction for primary malignant tumors. Ann Thorac Surg 2004;77:1001-6.

6. Mahabir RC, Butler CE. Stabilization of the chest wall: autologous and alloplastic reconstructions. Semin Plast Surg 2011;25:34-42.

7. Sanna S, Brandolini J, Pardolesi A, Argnani D, Mengozzi M, Dell'Amore A, et al. Materials and techniques in chest wall reconstruction: a review. J Vis Surg 2017;3:95.

8. Turna A, Kavakli K, Sapmaz E, Arslan H, Caylak H, Gokce HS, et al. Reconstruction with a patient-specific titanium implant after a wide anterior chest wall resection. Interact Cardiovasc Thorac Surg 2014;18:234-6.

9. Aragón J, Pérez Méndez I. Dynamic 3D printed titanium copy prosthesis: a novel design for large chest wall resection and reconstruction. J Thorac Dis 2016;8:E385-9. 